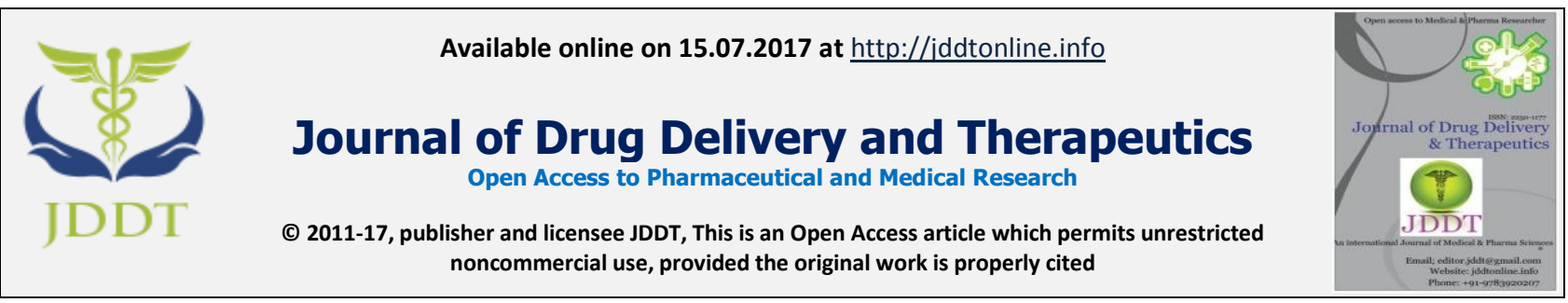

Open $\odot$ Access

Research Article

\title{
METHOD DEVELOPMENT AND VALIDATION OF IRBESARTAN \\ CHLORTHALIDONE AND CILNIDIPINE IN THEIR COMBINED TABLET DOSAGE FORM BY HIGH PERFORMANCE LIQUID CHROMATOGRAPHY
}

\author{
Rishabh K Dagariya, Rakesh K Jat, \\ Institute of Pharmacy, Shri Jagadish Prasad Jhabarmal Tibrewala University, Jhunjhunu, Rajasthan
}

\section{ABSTRACT}

The present work describes a validated reverse phase high performance liquid chromatographic method for simultaneous estimation of Irbesartan chlorthalidone and cilnidipine in tablet dosage form. The quantification was carried out using C18 column (250 x $4.6 \mathrm{~mm}, 5 \mu \mathrm{m})$ and mobile phase comprised of Buffer, Acetonitrile and TEA in a proportion of 80:20:0.1 \%v/v/v. The flow rate was $1.0 \mathrm{ml} / \mathrm{min}$ and the eluent was monitored at $222 \mathrm{~nm}$. The selected chromatographic conditions were found to effectively separate Irbesartan Chlorthalidone and cilnidipine were $3.807 \mathrm{~min}, 4.667 \mathrm{~min}$, and $6.887 \mathrm{~min}$ respectively. Linearity was found to be in the range of $30-90 \mu \mathrm{g} / \mathrm{ml}, 1.25-3.75 \mu \mathrm{g} / \mathrm{ml}$ and $1-3 \mu \mathrm{g} / \mathrm{ml}$ for Irbesartan Chlorthalidone and cilnidipine respectively. The percentage recoveries of all the drugs were found to be $99.27-99.81 \%, 99.57-99.99 \%$ and $99.22-99.44 \%$ for Irbesartan, chlorthalidone, and cilnidipine. The proposed method was found to be fast, accurate, precise, and reproducible and can be used for simultaneous estimation of these drugs in a tablet.

Keywords: Irbesartan, chlorthalidone and cilnidipine, Reversed-phase HPLC.

Article Info: Received 28 May, 2017; Review Completed 11 July, 2017; Accepted 12 July, 2017; Available online 15 July, 2017

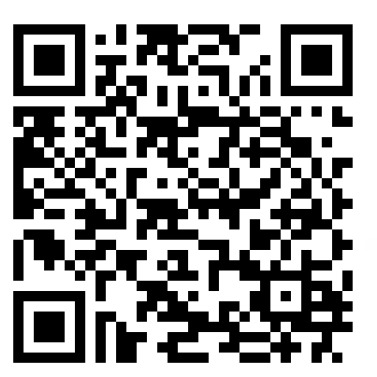

\section{Cite this article as: Delivery and Therapeutics. 2017; 7(4):88-96 \\ DOI: http://dx.doi.org/10.22270/jddt.v7i4.1471 \\ *Address for Correspondence}

Dagariya RK, Jat RK, Method development and validation of Irbesartan chlorthalidone and Cilnidipine in their combined tablet dosage form by high performance liquid chromatography, Journal of Drug

Rishabh K Dagariya, Institute of Pharmacy, Shri Jagadish Prasad Jhabarmal Tibrewala University, Jhunjhunu, Rajasthan, India Email: rishabhdagariya@gmail.com

\section{INTRODUCTION}

Irbesartan is an angiotensin converting enzyme blocker As with all angiotensin II receptor antagonists, irbesartan is indicated for the treatment of hypertension. It may also delay progression of diabetic nephropathy and is also indicated for the reduction of renal disease progression in patients with type 2 diabetes, hypertension and microalbuminuria (>30 mg/24 hours) or proteinuria (>900 mg/24 hours)

Chlorthalidone is a diuretic drug used to treat hypertension, Compared with other medications of the thiazide class, chlortalidone has the longest duration of action but a similar diuretic effect at maximal therapeutic doses.Chlorthalidone of (RS)-2-Chloro-5-(1-
hydroxy-3-oxo-2,3-dihydro-1H-isoindol-1-yl)benzene1 -sulfonamide, represents the class of Chlortalidone is a diuretic drug used to treat hypertension Chlortalidone has the longest duration of action but a similar diuretic effect at maximal therapeutic doses., used as an Antihypertensive agent. ${ }^{1-2}$ Chlorthalidone inhibits sodium ion transport across the renal tubular epithelium in the cortical diluting segment of the ascending limb of the loop of Henle. By increasing the delivery of sodium to the distal renal tubule, Chlorthalidone indirectly increases potassium excretion via the sodium-potassium exchange mechanism. The individual and combination with other drugs determination of Chlorthalidone has been carried out by UV spectrophotometer ${ }^{3}$, RP-HPLC ${ }^{4-6}$ in bulk and solid dosage forms. Cilnidipine of O3-(2- 
methoxyethyl)O5-[(E)-3-phenylprop-2-enyl]2,6dimethyl-4-(3-nitrophenyl)-1,4-dihydropyridine$3,5-$ dicarboxylate belongs to Anti hypertensive. ${ }^{7-9}$ Literature survey revealed that few analytical methods have been reported for the estimation of Cilnidipine included RPHPLC $^{10-11}$ UV spectrophotometer. ${ }^{12-13}$.Cilnidipine is a dual L-/N-type calcium channel protein inhibitor and blocker. Cilnidipine has displayed renal and vascular protective effects and improved baroreflex sensitivity in patients with hypertension. The present work describes a validated reverse phase HPLC method for simultaneous determination of these drugs in tablets.

\section{MATERIALS AND METHODS}

Reagents and Chemicals: Irbesartan, chlorthalidone and cilnidipine were received as a gift sample from Molecule laboratory, Acetonitrile of HPLC grade, Triethyl amine of HPLC grade, Water of HPLC grade.

Instruments and Chromatographic Conditions: LC10AT HPLC system was used for method development, degradation studies and validation. Data acquisition was performed on Spinchrom HPLC software. The separation were achieved on C18 $(250 \times 4.6 \mathrm{~mm}, 5 \mu \mathrm{m})$ column. The column was maintained at room temperature and the eluent was monitored at $222 \mathrm{~nm}$ using UV detector. The mixture of Potassium dihydrogen phosphate buffer $0.05 \mathrm{M}$ ( $\mathrm{pH}$ 3.5): Acetonitrile: TEA (80:20:0.1 v/v) at a flow rate of 1.0 $\mathrm{ml} / \mathrm{min}$ was used as a mobile phase. The injection volume was $20 \mu 1$.

\section{Preparation of standard solutions:}

\section{Irbesartan standard stock solution: $(600 \mu \mathrm{g} / \mathrm{mL})$}

A $60 \mathrm{mg}$ of Irbesartan was weighed and transferred to a $100 \mathrm{~mL}$ volumetric flask. Volume was made up to the mark with methanol.

\section{Cilnidipine standard stock solution: $(20 \mu \mathrm{g} / \mathrm{mL})$}

A $20 \mathrm{mg}$ of Cilnidipine was weighed and transferred to a $100 \mathrm{~mL}$ volumetric flask. Volume was made up to the mark with methanol. Take $10 \mathrm{ml}$ from this solution and transferred to $100 \mathrm{~mL}$ volumetric flask and volume made up to the mark by mobile phase.

\section{Chlorthalidone standard stock solution: $(25 \mu \mathrm{g} / \mathrm{mL})$}

A $25 \mathrm{mg}$ of Chlorthalidone was weighed and transferred to a $100 \mathrm{~mL}$ volumetric flask. Volume was made up to the mark with methanol. Take $10 \mathrm{ml}$ from this solution and transferred to $100 \mathrm{~mL}$ volumetric flask and volume made up to the mark by mobile phase.

Preparation of standard solution of mixtures of Irbesartan $(60 \mu \mathrm{g} / \mathrm{mL})$,Cilnidipine $(2 \mu \mathrm{g} / \mathrm{mL})$ and Chlorthalidone $(2.5 \mu \mathrm{g} / \mathrm{mL})$

Take $1 \mathrm{~mL}$ from the Irbesartan stock solution, $1 \mathrm{~mL}$ from Cilnidipine stock solution and $1 \mathrm{~mL}$ from Chlorthalidone stock solution and transferred to $10 \mathrm{~mL}$ volumetric flask and volume made up to the mark by mobile phase which was used in particular trials.

\section{Preparation of Mobile phase:}

Potassium dihydrogen phosphate buffer $0.05 \mathrm{M}$ ( $\mathrm{pH} 3.5)$ : Acetonitrile: TEA (80:20:0.1 v/v)

\section{Preparation of sample solution:}

Take Crushed Tablet powder equivalent to $60 \mathrm{mg}$ of Irbesartan, $2.5 \mathrm{mg}$ Chlorthalidone and $2 \mathrm{mg}$ of Cilnidipine was transferred to a $100 \mathrm{ml}$ volumetric flask, and made up volume up to the mark with mobile phase. The solution was filtered through whatman filter paper no. 42 and first few drops of filtrate were discarded. $10 \mathrm{ml}$ of this solution was diluted to $100 \mathrm{ml}$ with mobile phase. The solution was injected $20 \mu \mathrm{l}$. The areas of resulting peak were measured at $222 \mathrm{~nm}$.

\section{Validation of RP-HPLC method}

\section{Linearity}

The linearity for Irbesartan, Cilnidipine and Chlorthalidone were assessed by analysis of combined standard solution in range of $30-90 \mu \mathrm{g} / \mathrm{ml}$, $1-3 \mu \mathrm{g} / \mathrm{ml}$ and $1.25-3.75 \mu \mathrm{g} / \mathrm{ml}$ respectively,

$5,7.5,10,12.5,15 \mathrm{ml}$ solutions were pipette out from the Stock solution of Irbesartan $(60 \mu \mathrm{g} / \mathrm{ml})$, Cilnidipine (2 $\mu \mathrm{g} / \mathrm{ml})$ and Chlorthalidone $(2.5 \mu \mathrm{g} / \mathrm{ml})$ and transfer to $100 \mathrm{ml}$ volumetric flask and make up with mobile phase to obtain $30,45,60,75$ and $90 \mu \mathrm{g} / \mathrm{ml}, 1,1.5,2,2.5$ and 3 $\mu \mathrm{g} / \mathrm{ml}$ and $1.25,1.875,2.5,3.125$ and $3.75 \mu \mathrm{g} / \mathrm{ml}$ for Irbesartan, Cilnidipine and Chlorthalidone respectively

In term of slope, intercept and correlation co-efficient value. The graph of peak area obtained verses respective concentration was plotted.

\section{Precision}

Results should be expressed as Relative standard deviation (RSD) or coefficient of variance.

\section{A. Repeatability}

Standard solution containing Irbesartan $(60 \mu \mathrm{g} / \mathrm{ml})$, Cilnidipine $(2 \mu \mathrm{g} / \mathrm{ml})$ and Chlorthalidone $(2.5 \mu \mathrm{g} / \mathrm{ml})$ was injected six times and areas of peaks were measured and \% R.S.D. was calculated.

\section{B. Intra-day precision}

Standard solution containing $(30,60,90 \mu \mathrm{g} / \mathrm{ml})$ of Irbesartan and $(1,2,3 \mu \mathrm{g} / \mathrm{ml})$ of Cilnidipine and $(1.25,2.5,3.75 \mu \mathrm{g} / \mathrm{ml})$ of Chlorthalidone were analyzed three times on the same day and \% R.S.D was calculated.

\section{Inter-day precision}

Standard solution containing $(30,60,90 \mu \mathrm{g} / \mathrm{ml})$ of Irbesartan and $(1,2,3 \mu \mathrm{g} / \mathrm{ml})$ of Cilnidipine and $(1.25,2.5,3.75 \mu \mathrm{g} / \mathrm{ml})$ of Chlorthalidone were analyzed three times on the different day and \% R.S.D was calculated.

\section{Accuracy}

For Irbesartan

$30 \mu \mathrm{g} / \mathrm{ml}$ drug solution was taken in three different flask label A, B and C. Spiked 80\%, 100\%, 120\% of standard solution in it and diluted up to $10 \mathrm{ml}$. The area of each solution peak was measured at $222 \mathrm{~nm}$. The amount of 
Irbesartan was calculated at each level and \% recoveries were computed.

\section{For Cilnidipine}

$1 \mu \mathrm{g} / \mathrm{ml}$ drug solution was taken in three different flask label A, B and C. Spiked 80\%, 100\%, $120 \%$ of standard solution in it and diluted up to $10 \mathrm{ml}$. The area of each solution peak was measured at $222 \mathrm{~nm}$. The amount of Cilnidipine was calculated at each level and \% recoveries were computed.

For Chlorthalidone

$1.25 \mu \mathrm{g} / \mathrm{ml}$ drug solution was taken in three different flask label A, B and C. Spiked 80\%, 100\%, 120\% of standard solution in it and diluted up to $10 \mathrm{ml}$. The area of each solution peak was measured at $222 \mathrm{~nm}$. The amount of Chlorthalidone was calculated at each level and $\%$ recoveries were computed.

\section{LOD and LOQ}

The LOD was estimated from the set of 3 calibration curves used to determination method linearity. The LOD may be calculated as,

$\mathrm{LOD}=3.3 \times(\mathrm{SD} / \mathrm{Slope})$

Where,
$\mathrm{SD}=$ Standard deviation of $\mathrm{Y}$-intercepts of 3 calibration curves.

Slope $=$ Mean slope of the 3 calibration curves.

The LOQ was estimated from the set of 3 calibration curves used to determine method linearity. The LOQ may be calculated as,

$\mathrm{LOQ}=10 \times(\mathrm{SD} /$ Slope $)$

Where,

$\mathrm{SD}=$ Standard deviation of $\mathrm{Y}$-intercepts of 3 calibration curves.

Slope $=$ Mean slope of the 3 calibration curves.

\section{Robustness}

Following parameters were changed one by one and their effect was observed on system suitability for standard preparation.

1. Flow rate of mobile phase was changed $( \pm 0.2$ $\mathrm{ml} / \mathrm{min}$ ) $0.8 \mathrm{ml} / \mathrm{min}$ and $1.2 \mathrm{ml} / \mathrm{min}$.

2. $\mathrm{pH}$ of Mobile phase was changed $( \pm 0.2) 3.3$ and 3.5.

3. Ratio of Mobile phase was changed $( \pm 2)$ Buffer: Acetonitrile (82:18) and Buffer: Acetonitrile (78:22)

\section{RESULT AND DISCUSSION}

\section{Specificity:}

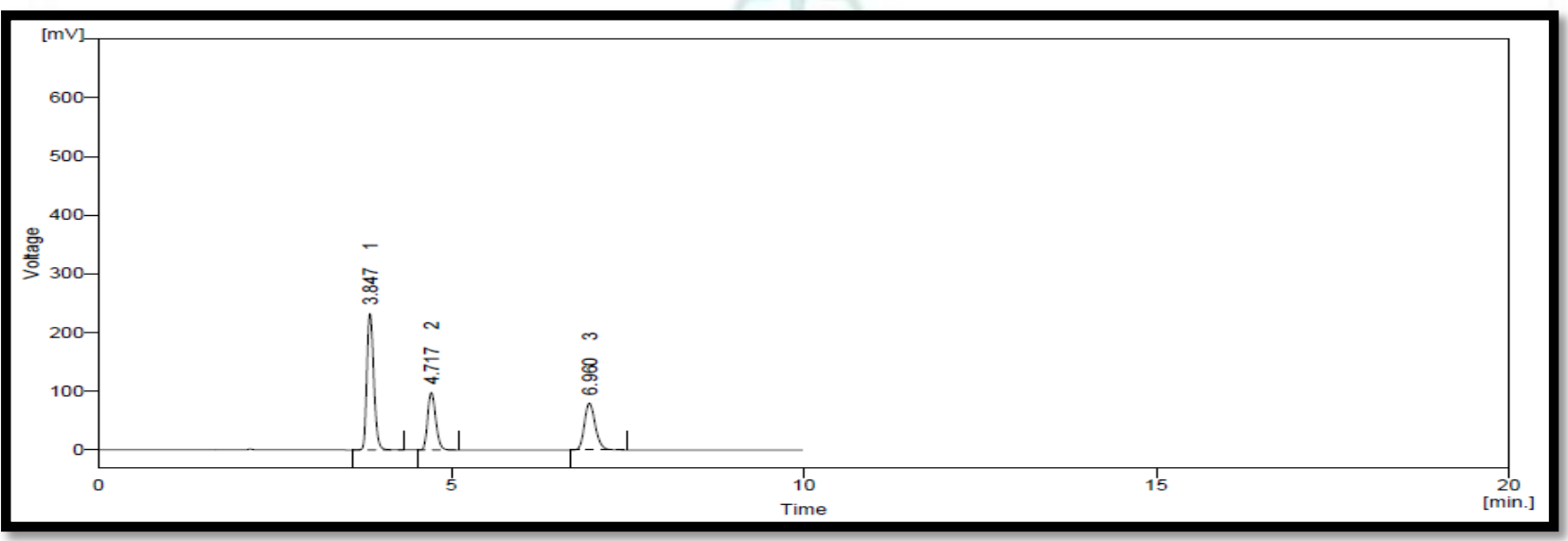

Figure 1: Chromatogram of Irbesartan, Chlorthalidone and Cilnidipine standard

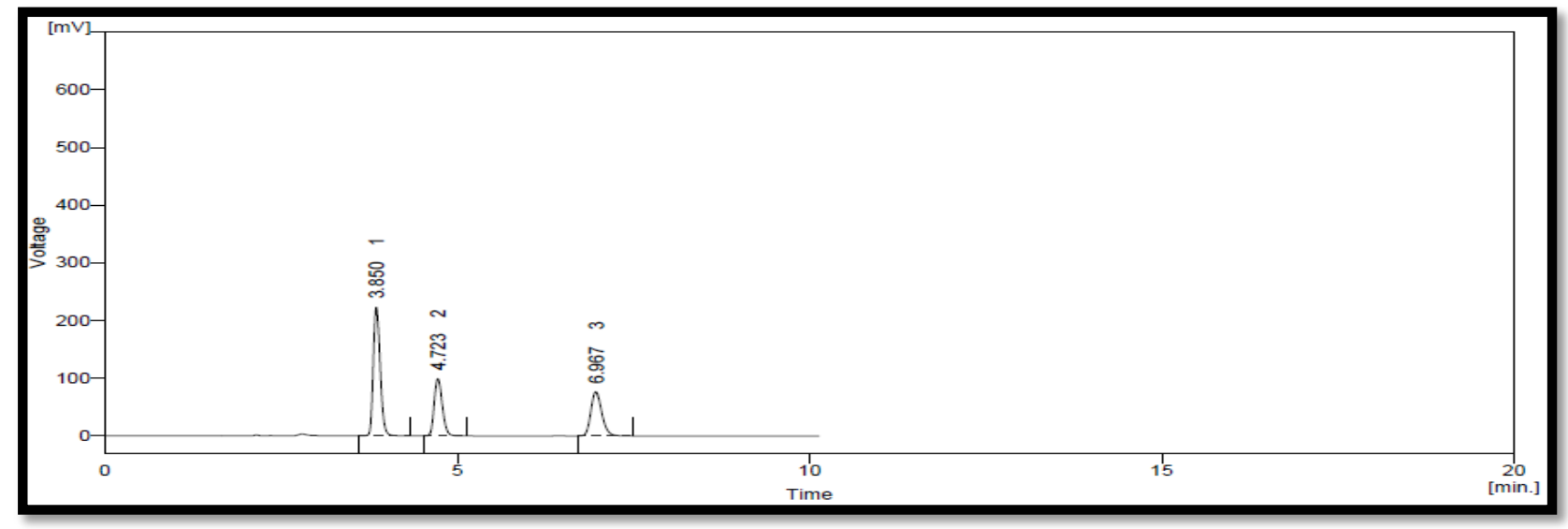


Figure 2: Chromatogram of Irbesartan, Chlorthalidone and Cilnidipine sample

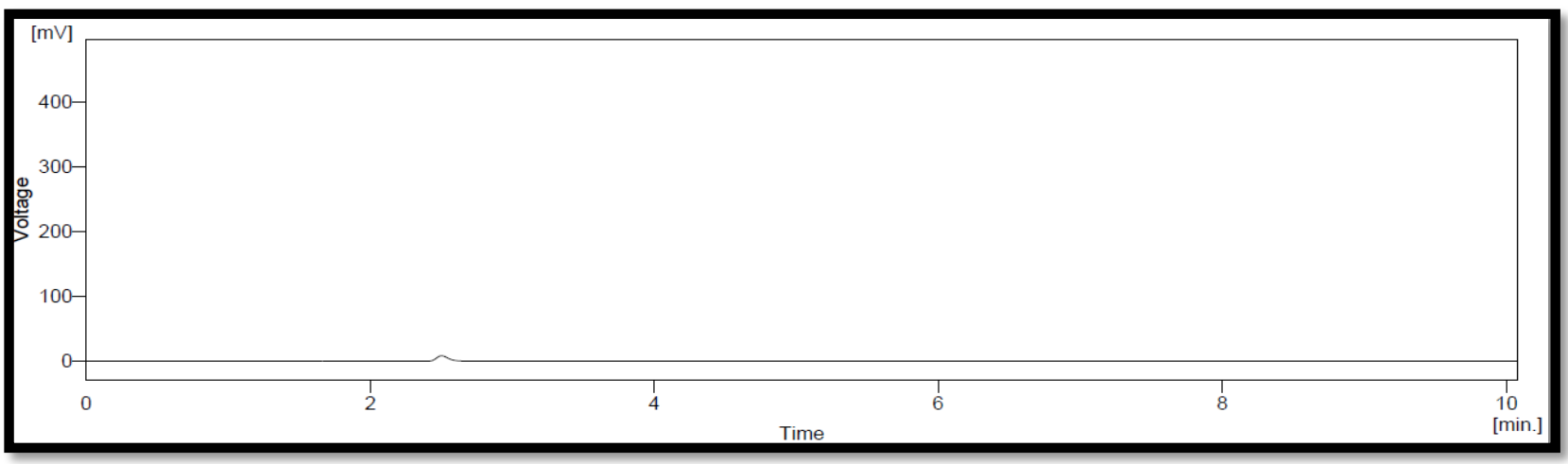

Figure 3: Chromatogram of Irbesartan, Chlorthalidone and Cilnidipine Blank

The Chromatograms of Irbesartan, Chlorthalidone and Cilnidipine standards and Irbesartan, Chlorthalidone and Cilnidipine sample show no interference with the Chromatogram of Irbesartan, Chlorthalidone and Cilnidipine Blank, so the Developed method is Specific.

\section{Linearity and Range}

The linearity for Irbesartan, Cilnidipine and Chlorthalidone were assessed by analysis of combined standard solution in range of 30-90 $\mu \mathrm{g} / \mathrm{ml}, 1-3 \mu \mathrm{g} / \mathrm{ml}$ and $1.25-3.75 \mu \mathrm{g} / \mathrm{ml}$ respectively. Correlation co-efficient for calibration curve Irbesartan, Cilnidipine and Chlorthalidone was found to be 0.999 for all of three.

The regression line equation for Irbesartan, Cilnidipine and Chlorthalidone are as following:

For Irbesartan:

$$
y=26.20 x-10.80 \text { and }
$$

For Chlorthalidone:

$$
y=311.1 x-5.764 \text { and }
$$

For Cilnidipine

$$
y=425.9 x-5.533
$$

Table 1: Linearity data for Irbesartan

\begin{tabular}{|c|c|c|}
\hline Sr.No & Concentration $(\mu \mathrm{g} / \mathrm{ml})$ & Area \\
\hline 1 & 30 & 776.733 \\
\hline 2 & 45 & 1162.735 \\
\hline 3 & 60 & 1570.086 \\
\hline 4 & 75 & 1949.034 \\
\hline 5 & 90 & 2348.984 \\
\hline
\end{tabular}

Table 2: Linearity data for Chlorthalidone

\begin{tabular}{|c|c|c|}
\hline Sr. No & Concentration $(\mu \mathrm{g} / \mathrm{ml})$ & Area \\
\hline 1 & 1.25 & 384.037 \\
\hline 2 & 1.875 & 574.785 \\
\hline 3 & 2.5 & 776.051 \\
\hline 4 & 3.125 & 963.331 \\
\hline 5 & 3.75 & 1162.027 \\
\hline
\end{tabular}

Table 3: Linearity data for Cilnidipine

\begin{tabular}{|c|c|c|}
\hline Sr. No & Concentration $(\mu \mathrm{g} / \mathrm{ml})$ & Area \\
\hline 1 & 1 & 420.91 \\
\hline 2 & 1.5 & 630.213 \\
\hline 3 & 2 & 851.093 \\
\hline 4 & 2.5 & 1056.653 \\
\hline 5 & 3 & 1272.432 \\
\hline
\end{tabular}


Figure 4: Overlay chromatogram of different concentrations of mixtures of Irbesartan, Cilnidipine and Chlorthalidone

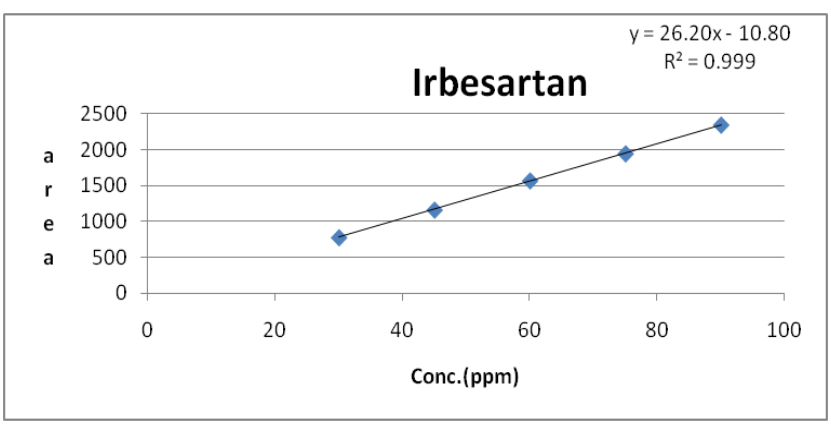

Figure 5: Calibration Curve of Irbesartan $(30-90 \mu \mathrm{g} / \mathrm{ml})$

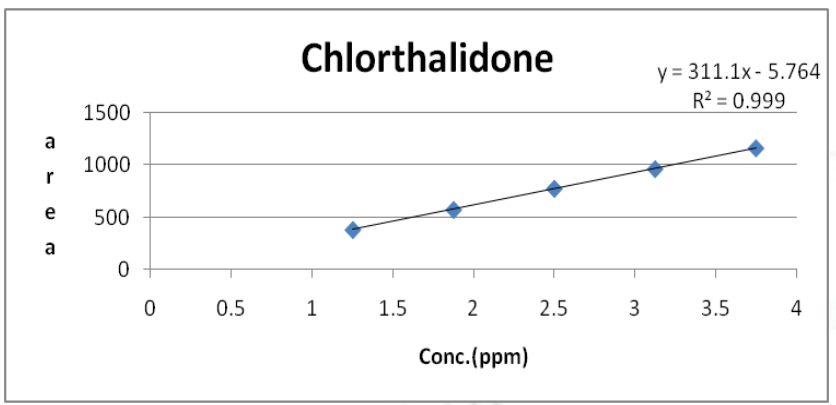

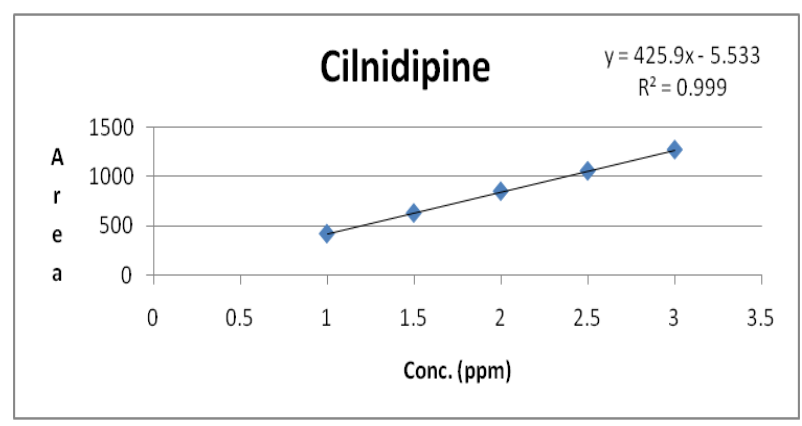

Figure 7: Calibration Curve of Cilnidipine (1-3 $\mu \mathrm{g} / \mathrm{ml})$

\section{Precision}

\section{Repeatability}

The data for repeatability of peak area measurement for $\operatorname{Irbesartan}(60 \mu \mathrm{g} / \mathrm{ml})$, Cilnidipine $(2 \mu \mathrm{g} / \mathrm{ml})$ and Chlorthalidone $(2.5 \mu \mathrm{g} / \mathrm{ml})$, based on six measurements of same solution of Irbesartan (60 $\mu \mathrm{g} / \mathrm{ml})$, Cilnidipine $(2 \mu \mathrm{g} / \mathrm{ml})$ and Chlorthalidone $(2.5$ $\mu \mathrm{g} / \mathrm{ml})$ are depicted in table. The \% RSD for Irbesartan, Chlorthalidone and Cilnidipine were found to be 0.271 , 0.249 and 0.154 respectively.

Figure 6: Calibration Curve of Chlorthalidone (1.25$3.75 \mu \mathrm{g} / \mathrm{ml}$ )

Table 4: Repeatability data for Irbesartan

\begin{tabular}{|c|c|c|c|c|}
\hline \multicolumn{5}{|c|}{ Irbesartan } \\
\hline Sr No. & Conc $(\mu \mathrm{g} / \mathrm{ml})$ & Area & Mean \pm S.D $(n=6)$ & $\%$ R.S.D \\
\hline \multirow{6}{*}{1.} & \multirow{6}{*}{60} & 1565.283 & \multirow{6}{*}{$1568.45 \pm 4.25$} & \multirow{6}{*}{0.271} \\
\hline & & 1563.976 & & \\
\hline & & 1566.882 & & \\
\hline & & 1570.032 & & \\
\hline & & 1568.622 & & \\
\hline & & 1575.875 & & \\
\hline
\end{tabular}

Table 5: Repeatability data for Chlorthalidone

\begin{tabular}{|c|c|c|c|c|}
\hline \multicolumn{5}{|c|}{ Chlorthalidone } \\
\hline Sr No. & Conc $(\mu \mathrm{g} / \mathrm{ml})$ & Area & Mean \pm S.D $(n=6)$ & $\%$ R.S.D \\
\hline \multirow{6}{*}{1.} & \multirow{6}{*}{2.5} & 773.736 & \multirow{6}{*}{$775.93 \pm 1.93$} & \multirow{6}{*}{0.249} \\
\hline & & 775.27 & & \\
\hline & & 774.495 & & \\
\hline & & 776.049 & & \\
\hline & & 776.831 & & \\
\hline & & 779.169 & & \\
\hline
\end{tabular}

Table 6: Repeatability data for Cilnidipine

\begin{tabular}{|c|c|c|c|c|}
\hline \multicolumn{5}{|c|}{ Cilnidipine } \\
\hline \multirow{3}{*}{ Sr No. } & Conc $(\mu \mathrm{g} / \mathrm{ml})$ & Area & Mean \pm S.D $(\mathrm{n}=6)$ & \% R.S.D \\
\hline \multirow{3}{*}{1.} & \multirow{3}{*}{2} & 848.569 & & \\
\cline { 2 - 3 } & & 850.25 & & \multirow{2}{*}{1.153} \\
\cline { 2 - 3 } & & 849.382 & $850.45 \pm 1.30$ & \\
\cline { 2 - 3 } & & 851.102 & & \\
\end{tabular}




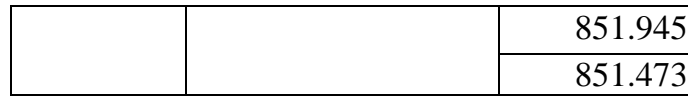

\section{Intraday precision}

The data for intraday precision for Irbesartan, Cilnidipine and Chlorthalidone is shown in table
6.10. The \% R.S.D for Intraday precision was found to be $0.148-0.554$ for Irbesartan and $0.198-0.312$ for Chlorthalidone and 0.568-1.062 for Cilnidipine.

Table 7: Intraday precision data for estimation of Irbesartan

\begin{tabular}{|c|c|c|c|}
\hline & \multicolumn{3}{|c|}{ Irbesartan } \\
\hline SR. NO. & $\begin{array}{c}\text { Conc. } \\
(\mu \mathrm{g} / \mathrm{ml})\end{array}$ & $\begin{array}{c}\text { Area } \\
\text { Mean } \pm \text { S.D. }(\mathrm{n}=3)\end{array}$ & $\%$ R.S.D \\
\hline 1 & 30 & $769.78 \pm 2.76$ & 0.359 \\
\hline 2 & 60 & $1558.92 \pm 2.31$ & 0.148 \\
\hline 3 & 90 & $3498.33 \pm 19.38$ & 0.554 \\
\hline
\end{tabular}

Table 8: Intraday precision data for estimation of Chlorthalidone

\begin{tabular}{|c|c|c|c|}
\hline & \multicolumn{3}{|c|}{ Chlorthalidone } \\
\hline SR. NO. & $\begin{array}{c}\text { Conc. } \\
(\mu \mathrm{g} / \mathrm{ml})\end{array}$ & $\begin{array}{c}\text { Area } \\
\text { Mean } \pm \text { S.D. }(\mathrm{n}=3)\end{array}$ & \% R.S.D \\
\hline 1 & 1.25 & $381.73 \pm 0.76$ & 0.198 \\
\hline 2 & 2.5 & $771.40 \pm 1.53$ & 0.200 \\
\hline 3 & 3.75 & $1734.56 \pm 5.42$ & 0.312 \\
\hline
\end{tabular}

Table 9: Intraday precision data for estimation of Cilnidipine

\begin{tabular}{|c|c|c|c|}
\hline & \multicolumn{3}{|c|}{ Cilnidipine } \\
\hline SR. NO. & $\begin{array}{c}\text { Conc. } \\
(\mu \mathrm{g} / \mathrm{ml})\end{array}$ & $\begin{array}{c}\text { Area } \\
\text { Mean } \pm \text { S.D. }(\mathrm{n}=3)\end{array}$ & \% R.S.D \\
\hline 1 & 1 & $416.24 \pm 3.80$ & 0.914 \\
\hline 2 & 2 & $844.11 \pm 4.80$ & 0.568 \\
\hline 3 & 3 & $1886.32 \pm 20.03$ & 1.062 \\
\hline
\end{tabular}

\section{Interday precision}

The data for intraday precision Irbesartan, Cilnidipine and Chlorthalidone is shown in table 5.11. The \% RSD for interday precision was found to be $0.236-0.978$ for Irbesartan and 0.198-0.805 for Chlorthalidone and 0.384-1.029 for Cilnidipine

.. Table 10: Interday precision data for estimation of Irbesartan

\begin{tabular}{|c|c|c|c|}
\hline & \multicolumn{3}{|c|}{ Irbesartan } \\
\hline SR. NO. & $\begin{array}{c}\text { Conc. } \\
(\mu \mathrm{g} / \mathrm{ml})\end{array}$ & $\begin{array}{c}\text { Area } \\
\text { Mean } \pm \text { S.D. }(\mathrm{n}=3)\end{array}$ & \% R.S.D \\
\hline 1 & 30 & $769.55 \pm 1.82$ & 0.236 \\
\hline 2 & 60 & $1544.75 \pm 15.12$ & 0.979 \\
\hline 3 & 90 & $3502.97 \pm 8.83$ & 0.252 \\
\hline
\end{tabular}

Table 11: Interday precision data for estimation of Chlorthalidone

\begin{tabular}{|c|c|c|c|}
\hline & \multicolumn{3}{|c|}{ Chlorthalidone } \\
\hline SR. NO. & $\begin{array}{c}\text { Conc. } \\
(\mu \mathrm{g} / \mathrm{ml})\end{array}$ & $\begin{array}{c}\text { Area } \\
\text { Mean } \pm \text { S.D. }(\mathrm{n}=3)\end{array}$ & \% R.S.D \\
\hline 1 & 1.25 & $381.36 \pm 0.76$ & 0.199 \\
\hline 2 & 2.5 & $768.07 \pm 5.82$ & 0.757 \\
\hline 3 & 3.75 & $1723.19 \pm 13.88$ & 0.806 \\
\hline
\end{tabular}


Table 12: Interday precision data for estimation of Cilnidipine

\begin{tabular}{|c|c|c|c|}
\hline & \multicolumn{2}{|c|}{ Cilnidipine } \\
\hline SR. NO. & $\begin{array}{c}\text { Conc. } \\
(\mu \mathrm{g} / \mathrm{ml})\end{array}$ & $\begin{array}{c}\text { Area } \\
\text { Mean } \pm \text { S.D. }(\mathrm{n}=3)\end{array}$ & \% R.S.D \\
\hline 1 & 1 & $416.99 \pm 1.60$ & 0.385 \\
\hline 2 & 2 & $843.80 \pm 4.56$ & 0.540 \\
\hline 3 & 3 & $1886.90 \pm 19.43$ & 1.29 \\
\hline
\end{tabular}

\section{Accuracy:}

Accuracy of the method was confirmed by recovery study from marketed formulation at three level of standard addition. The results are shown in table 6.12 and 6.13. Percentage recovery for Irbesartan was 99.27-99.81 \% and Chlorthalidone, it was found to be in range of 99.57-99.99\% and for Cilnidipine 99.22-99.44\%

Table 13: Recovery data for Irbesartan

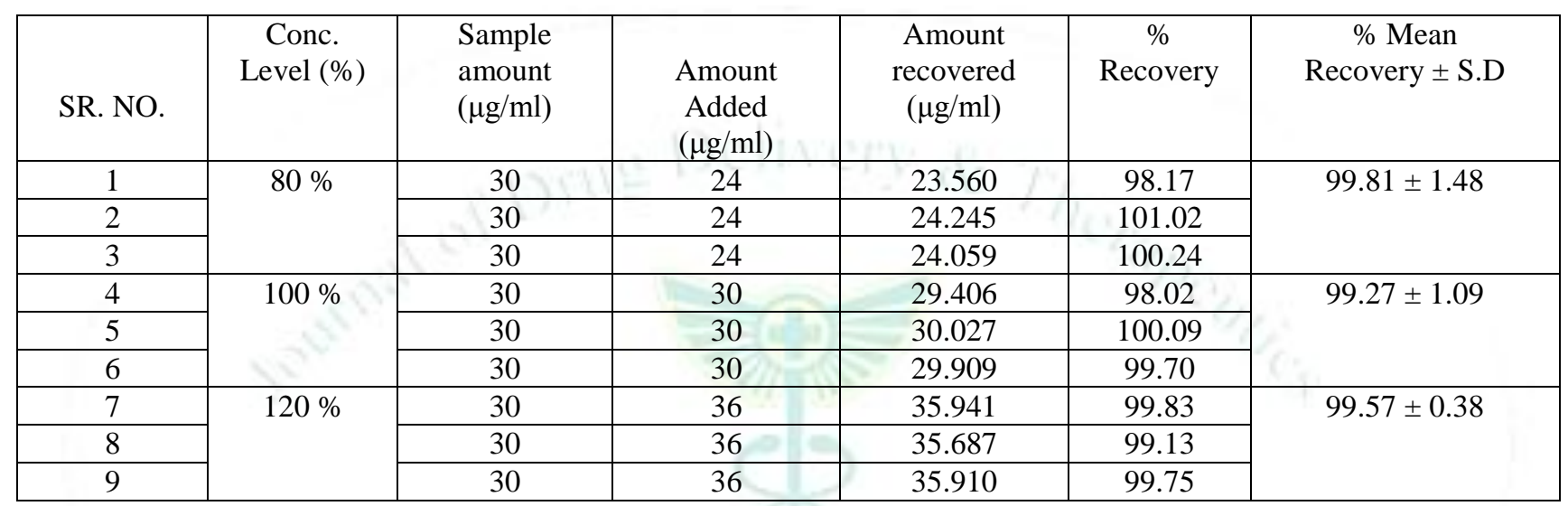

Table 14: Recovery data for Chlorthalidone

\begin{tabular}{|c|c|c|c|c|c|c|}
\hline SR. NO. & $\begin{array}{c}\text { Conc. } \\
\text { Level (\%) }\end{array}$ & $\begin{array}{l}\text { Sample } \\
\text { Amount }\end{array}$ & $\begin{array}{l}\text { Amount } \\
\text { Added }\end{array}$ & $\begin{array}{c}\text { Amount } \\
\text { recovered } \\
(\mu \mathrm{g} / \mathrm{ml})\end{array}$ & $\begin{array}{c}\% \\
\text { Recovery }\end{array}$ & $\begin{array}{c}\% \text { Mean } \\
\text { Recovery } \pm \text { S.D }\end{array}$ \\
\hline 1 & \multirow[t]{3}{*}{$80 \%$} & 1.25 & 1 & 0.988 & 98.77 & \multirow[t]{3}{*}{$99.99 \pm 1.12$} \\
\hline 2 & & 1.25 & 1 & 1.010 & 100.99 & \\
\hline 3 & & 1.25 & 1 & 1.002 & 100.22 & \\
\hline 4 & \multirow[t]{3}{*}{$100 \%$} & 1.25 & 1.25 & 1.237 & 98.97 & \multirow[t]{3}{*}{$99.57 \pm 0.56$} \\
\hline 5 & & 1.25 & 1.25 & 1.251 & 100.07 & \\
\hline 6 & & 1.25 & 1.25 & 1.246 & 99.67 & \\
\hline 7 & \multirow[t]{3}{*}{$120 \%$} & 1.25 & 1.5 & 1.504 & 100.28 & \multirow[t]{3}{*}{$99.70 \pm 0.59$} \\
\hline 8 & & 1.25 & 1.5 & 1.487 & 99.10 & \\
\hline 9 & & 1.25 & 1.5 & 1.496 & 99.72 & \\
\hline
\end{tabular}

Table 15: Recovery data for Cilnidipine

\begin{tabular}{|c|c|c|c|c|c|c|}
\hline SR. NO. & $\begin{array}{c}\text { Conc. } \\
\text { Level (\%) }\end{array}$ & $\begin{array}{l}\text { Sample } \\
\text { Amount }\end{array}$ & $\begin{array}{l}\text { Amount } \\
\text { Added }\end{array}$ & $\begin{array}{c}\text { Amount } \\
\text { recovered } \\
(\mu \mathrm{g} / \mathrm{ml})\end{array}$ & $\begin{array}{c}\% \\
\text { Recovery }\end{array}$ & $\begin{array}{c}\% \text { Mean } \\
\text { Recovery } \pm \text { S.D }\end{array}$ \\
\hline 1 & \multirow[t]{3}{*}{$80 \%$} & 1 & 0.8 & 0.791 & 98.88 & \multirow[t]{3}{*}{$99.41 \pm 0.80$} \\
\hline 2 & & 1 & 0.8 & 0.792 & 99.03 & \\
\hline 3 & & 1 & 0.8 & 0.803 & 100.33 & \\
\hline 4 & \multirow[t]{3}{*}{$100 \%$} & 1 & 1 & 0.991 & 99.08 & \multirow[t]{3}{*}{$99.22 \pm 0.51$} \\
\hline 5 & & 1 & 1 & 0.988 & 98.79 & \\
\hline 6 & & 1 & 1 & 0.998 & 99.79 & \\
\hline 7 & $120 \%$ & 1 & 1.2 & 1.205 & 100.41 & $99.44 \pm 1.22$ \\
\hline
\end{tabular}




\begin{tabular}{|l|l|l|l|}
\hline 8 & \multirow{2}{*}{9} & 1 & 1.2 \\
9 & 1 & 1.2 \\
\hline
\end{tabular}

\section{LOD and LOQ}

Calibration curve was repeated for five times and the standard deviation (SD) of the intercepts was calculated. Then LOD and LOQ were calculated as follows:

\begin{tabular}{l|r}
1.177 & 98.08 \\
\hline 1.198 & 99.84
\end{tabular}

$\mathrm{LOD}=3.3 * \mathrm{SD} /$ slope of calibration curve

$\mathrm{LOQ}=10 * \mathrm{SD} /$ slope of calibration curve

Where, SD = Standard deviation of intercepts

Table 16: Limit of Detection data for Irbesartan and Chlorthalidone and Cilnidipine

\begin{tabular}{|c|c|c|}
\hline Irbesartan & Chlorthalidone & Cilnidipine \\
\hline LOD = 3.3 $\times($ SD / Slope $)$ & LOD $=3.3 \times($ SD / Slope $)$ & LOD = 3.3 $\times($ SD / Slope $)$ \\
$=3.3 \times(26.20 / 10.80)$ & $=3.3 \times(311.1 / 5.764)$ & $=3.3 \times(425.9 / 5.533)$ \\
$=0.862 \mu \mathrm{g} / \mathrm{ml}$ & $=0.036 \mu \mathrm{g} / \mathrm{ml}$ & $=0.028 \mu \mathrm{g} / \mathrm{ml}$ \\
\hline
\end{tabular}

Table 17: Limit of Quantitation data or Irbesartan and Chlorthalidone and Cilnidipine

\begin{tabular}{|c|c|c|}
\hline Irbesartan & Chlorthalidone & Cilnidipine \\
\hline LOQ $=10 \times(\mathrm{SD} /$ Slope $)$ & LOQ $=10 \times($ SD $/$ Slope $)$ & LOQ $=10 \times($ SD $/$ Slope $)$ \\
$=10 \times(26.20 / 10.80)$ & $=10 \times(311.1 / 5.764)$ & $=10 \times(425.9 / 5.533)$ \\
$=2.612 \mu \mathrm{g} / \mathrm{ml}$ & $=0.111 \mu \mathrm{g} / \mathrm{ml}$ & $=0.085 \mu \mathrm{g} / \mathrm{ml}$ \\
\hline
\end{tabular}

\section{Robustness:}

The effect of changes was found to be within the acceptance criteria as shown in table 6.16 and table 6.17 . The $\%$ RSD should be less than $2 \%$.

Table 18: Robustness data for Irbesartan

\begin{tabular}{|c|c|c|c|c|c|c|}
\hline S N. & $\begin{array}{c}\text { Area at } \\
\text { Flow rate } \\
(-0.2 \mathrm{ml} / \mathrm{min})\end{array}$ & $\begin{array}{c}\text { Area at } \\
\text { Flow rate } \\
(+0.2 \mathrm{ml} / \mathrm{min})\end{array}$ & $\begin{array}{c}\text { Area at } \\
\mathrm{pH}(-0.2)\end{array}$ & $\begin{array}{c}\text { Area at } \\
\mathrm{pH}(+0.2)\end{array}$ & $\begin{array}{c}\text { Area at } \\
\text { Mobile phase (- } \\
2)\end{array}$ & $\begin{array}{c}\text { Area at } \\
\text { Mobile phase } \\
(+2)\end{array}$ \\
\hline 1 & 1611.009 & 1521.656 & 1597.439 & 1488.475 & 1595.100 & 1520.022 \\
\hline 2 & 1629.813 & 1533.886 & 1612.474 & 1502.462 & 1614.094 & 1533.886 \\
\hline \% & 1639.308 & 1538.695 & 1623.572 & 1508.516 & 1618.700 & 1544.878 \\
\hline \% R.S.D & 0.885 & 0.574 & 0.814 & 0.685 & 0.777 & 0.813 \\
\hline
\end{tabular}

Table 19: Robustness data for Chlorthalidone

\begin{tabular}{|c|c|c|c|c|c|c|}
\hline S N. & $\begin{array}{c}\text { Area at } \\
\text { Flow rate } \\
(-0.2 \mathrm{ml} / \mathrm{min})\end{array}$ & $\begin{array}{c}\text { Area at } \\
\text { Flow rate } \\
(+0.2 \mathrm{ml} / \mathrm{min})\end{array}$ & $\begin{array}{c}\text { Area at } \\
\mathrm{pH}(-0.2)\end{array}$ & $\begin{array}{c}\text { Area at } \\
\mathrm{pH}(+0.2)\end{array}$ & $\begin{array}{c}\text { Area at } \\
\text { Mobile phase } \\
(-2)\end{array}$ & $\begin{array}{c}\text { Area at } \\
\text { Mobile phase } \\
(+2)\end{array}$ \\
\hline 1 & 800.912 & 753.540 & 791.556 & 738.010 & 793.148 & 753.540 \\
\hline 2 & 805.609 & 758.188 & 801.985 & 742.655 & 797.837 & 758.188 \\
\hline 3 & 810.316 & 760.536 & 802.535 & 747.293 & 799.419 & 763.610 \\
\hline \% R.S.D & 0.584 & 0.470 & 0.775 & 0.625 & 0.409 & 0.665 \\
\hline
\end{tabular}

Table 20: Robustness data for Cilnidipine

\begin{tabular}{|c|c|c|c|c|c|c|}
\hline S. N. & $\begin{array}{c}\text { Area at } \\
\text { Flow rate } \\
(-0.2 \mathrm{ml} / \mathrm{min})\end{array}$ & $\begin{array}{c}\text { Area at } \\
\text { Flow rate } \\
(+0.2 \mathrm{ml} / \mathrm{min})\end{array}$ & $\begin{array}{c}\text { Area at } \\
\mathrm{pH}(-0.2)\end{array}$ & $\begin{array}{c}\text { Area at } \\
\mathrm{pH}(+0.2)\end{array}$ & $\begin{array}{c}\text { Area at } \\
\text { Mobile phase }(-2)\end{array}$ & $\begin{array}{c}\text { Area at } \\
\text { Mobile } \\
\text { phase }(+2)\end{array}$ \\
\hline 1 & 878.345 & 826.448 & 868.092 & 809.448 & 869.840 & 826.448 \\
\hline 2 & 871.187 & 819.804 & 871.991 & 805.584 & 872.866 & 821.574 \\
\hline 3 & 888.635 & 834.112 & 880.104 & 819.590 & 877.463 & 837.464 \\
\hline \% R.S.D & 0.997 & 0.866 & 0.702 & 0.891 & 0.439 & 0.983 \\
\hline
\end{tabular}




\section{Analysis of marketed formulation by developed method.}

Applicability of the proposed method was tested by analyzing the commercially available Tablet formulation Clindasartan- $\mathrm{CH}$. The results are shown in following table.

Table 21: Showing the analysis of marketed formulation by developed method

\begin{tabular}{|c|c|c|c|}
\hline Tablet & \multicolumn{3}{|c|}{ Clindasartan-CH } \\
\hline mg/Tablet powder & Irbesartan (150 mg) & Chlorthalidone (6.25 mg) & Cilnidipine (5 mg) \\
\hline $\begin{array}{c}\text { Assay (\% of label claim*) } \\
\text { Mean } \pm \text { S. D. }\end{array}$ & $100.05 \pm 0.544$ & $101.45 \pm 0.313$ & $100.92 \pm 0.277$ \\
\hline
\end{tabular}

The assay results were comparable to labeled value of each drug in Tablet dosage form. These results indicate that the developed method is accurate, precise, simple and rapid. It can be used in the routine quality control of dosage form in industries.

\section{CONCLUSION}

From the above discussion it can be concluded that the proposed method is precise, accurate and stability indicating. Results are in good agreement with label claim which indicates there is no interference of

\section{REFERENCES}

1. "Drug profile for Chlorthalidone", Sep 2015, http://www.drugbank.ca/drugs/DB00310

2. "Drug profile for Chlorthalidone", Sep 2015,http://en.wikipedia.org/wiki/ Chlorthalidone

3. "Drug profile for Cilnidipine", Sep 2015 , en.wikipedia.org/wiki/Cilnidipine.

4. "Drug profile for Cilnidipine", Sep 2015, www.drugbank.ca/drugs/DB03614

5. Niraimathi V, Jerad SA, Kumar SI. Uv Spectrophotometric Methods For The Estimation OF Chlorthalidone In Bulk and Oral Dosage Form. Indo American J. Pharm,2013; 3(9):7160-7167.

6. Rang and Del's Pharmacology; 6th Edn; Churchil levingstone Publishers (P) Ltd, New York, 2004, pp 277-285.

7. Dong WM. Modern HPLC for Practicing Scientists; A Wiley- Inter science publication, USA, 2006, pp 1-9.

8. Kazakevich Y and LoBrutto R. HPLC for pharmaceutical Scientists; A John Wiley and sons, 2007, pp 1-6.

9. Mhaske RA, Sahsrabhdhe S, mhaske AA, "RP-HPLC Method For Simultataneous Determination of Irbesartan, Losartan, Hydro-Chlorothiazide And ChlorthalidoneApplication To Commercially Available Drug Products" Int. j. pharm. Sci. and res., 2014; 1116-1123 excipients. Therefore the proposed method can be used for routine analysis of Irbesartan Chlorthalidone and Cilnidipine in combined tablet formulation.

\section{ACKNOWLEDGEMENT}

The authors are also thankful to Institute of Pharmacy, Shri Jagadish Prasad Jhabarmal Tibrewala University, Jhunjhunu, Rajasthan for providing necessary equipment, facility \& chemicals to complete research work.
10. Gandla K, Rao JS, Kumar JR, "New Stability Indicating Validated RP-HPLC Method for Simultaneous Estimation of Irbesartan and Atorvastatin in Combined Tablet Dosage Forms" Ame. J. pharm. Tech. res., 2015; 5(4):380-390

11. Gandla K, Suthakaran R, Kandoji P, "Development and Validation of RP-HPLC Method for Simultaneous Estimation of Irbesartan and Simvastatin in Tablet Dosage Form" Ame. J. pharm. And health res., 2014; 2(10):199-205

12. Patel S, Patel D" Simultaneous Determination of Metoprolol Succinate And Chlorthalidone By UV Spectrophotometric Method." Pharmagene. 2013; 1(3):39-43

13. Naazneen S, Sridevi A," Stability-Indicating RP-HPLC Method For The Simultaneous Estimation of Azilsartan Medoxomil And Chlorthalidone In Solid Dosage Forms." Int. J. of Pharm. and Pharm. Sci. 2014; 6(6):236-243

14. Saravanan V., Revathi R., Meera N. Method development and validation for the simultaneous estimation of lycopene and ubidecarenone by RP-HPLC in combined pharmaceutical dosage form. Journal of Drug Delivery and Therapeutics, 2016; 6(5): 46-51.

15. Lee KH, Park HJ, Shin CY, Myung CS "Pharmaceutical composition comprising cilnidipine and telmisartan", European Patents, PCT/KR2009/002539, 2010 